\title{
Penggunaan Media Pop Up Book dan Pengaruhnya Terhadap Peningkatan Pemahaman Siswa dalam Memahami Teks-Teks Bahasa Arab
}

\author{
Hasan Syukur \\ Institut Agama Islam Negeri (IAIN) Syekh Nurjati Cirebon \\ Email: Syukurhasan321@gmail.com \\ Sopwan Mulyawan \\ Institut Agama Islam Negeri (IAIN) Syekh Nurjati Cirebon \\ Email: sopmulyawan@gmail.com
}

\begin{abstract}
Abstrak
Penelitian ini bertujuan untuk mengetahui seberapa besar pengaruh penggunaan media pop book tehadap peningkatan pemahaman siswa dalam memahami teks-teks Bahasa Arab dalam pembelajaran Bahasa Aradi kelas VIII Mts An-Nur Kota Cirebon. Dasar pemikiran dari penelitian ini adalah bahwasanya media Pop Up Book merupakan salah satu media pembeljaran yang baru yang di arahkan untuk mempermudah siswa dalam memmahami pembelajaran. Media ini merupakan media yang efektif dalam pembelajaran bahasa arab, karena media ini mampu memberikan pemahaman bagi siswa dan membuat mereka lebih semangat lagi dalam belajar khususnya dalam mempelajari memahami teks-teks bahasa arab yang dibaca. Penelitian ini menggunakan metode kuantitatif dengan dengan jenis metode eksperimen. Medote pengumpulan data dalam penelitian ini adalah dengan cara observasi, tes dan wawancara, sedangkangkan analisis data dalam penelitian ini adalah dengan menggunakan penghitungan N-Gain,uji normalitas, uji homogenitas dan uji hipotesis. Hasil dari penelitian ini adalah bahawasanya pemahaman siswa dalam membaca teks-teks bahasa arab tanpa menggunakan media pop up book dikelas Eksperimen yaitu dengan nilai minimum 40, maksimum 75 dengan rata-rata 61, 25. Pemahaman siswa dalam membaca teks-teks bahasa arab dengan menggunakan media pop up book dikelas Eksperimen yaitu dengan nilai minimum 40, maksimum 98 dengan rata-rata 83, 18. Hal ini bermakana bahwasanya terdapat pengaruh penggunaan media pop up book terhadap peningkatan pemahaman siswa dalam memahami teks-teks bahasa arab yang dibaca.
\end{abstract}

Kata Kunci :Pop Up Book, Prmahaman Siswa, Teks-teks Bahasa Arab 


\section{Abstract}

This study aims to determine how much influence the use of pop book media on increasing student understanding in understanding Arabic texts in Ara Language learning in class VIII Mts An-Nur, Cirebon City. The rationale of this study is that the Pop Up Book media is one of the new learning media that is directed to facilitate students in understanding learning. This media is an effective medium in learning Arabic, because this media is able to provide understanding for students and make them more enthusiastic in learning, especially in learning to understand the Arabic texts that are read. This study uses a quantitative method with the type of experimental method. Medote data collection in this study is by observation, tests and interviews, while the analysis of data in this study is to use N-Gain calculation, normality test, homogeneity test and hypothesis test. The results of this study are that students understand the reading of Arabic texts without using the pop up book in the Experimental class, with a minimum value of 40 , a maximum of 75 with an average of 61,25 . Understanding students in reading Arabic texts using pop up book in the Experimental class, with a minimum value of 40 , a maximum of 98 with an average of 83,18 . It is assumed that there is an influence of the use of pop up book media to increase students' understanding in reading Arabic texts.

Keywords: Pop Up Book, Student Understanding, Arabic Texts

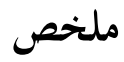

$$
\begin{aligned}
& \text { وأهداف البحث في هذه الرسالة لمعرفة فهم التلاميذ على النصوص العربية المقروءقفي الفصل الثامن } \\
& \text { بمدرسة النورالمتوسطة الإسلامية شربون.والأسس التفكيرية في هذا البحث هي أن وسيلة الكتاب } \\
& \text { المنبثق هيإحدى الوسائل التعليمية الجلديدة التي تتوجه لتسهيل التلاميذ في فهم الدرس. وهذه } \\
& \text { الوسيلة هي وسيلة فعّالة جدّا في تعليم اللغة العربية لأنّ هذه الوسيلةتدعو التلاميذ أن يفهموا المواد }
\end{aligned}
$$

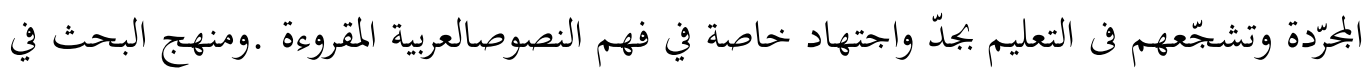

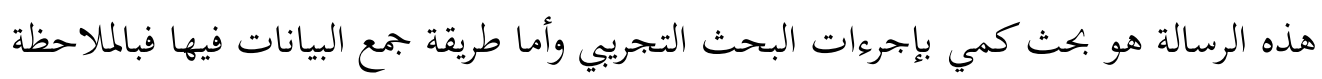

$$
\begin{aligned}
& \text { المباشرة والاختبار والمقابلة الشخصية. وطريقة تحليل البيانات التي استخدمها الباحث في هذا }
\end{aligned}
$$

البحث بحساب تقرير الفرقة (Gain) وبحربة العادية وبحربة المتجانس وبحربة الفروض Paired)

$$
\begin{aligned}
& \text { وحسبها بعد أن يحصل على البيانات من نتائج الاختبار القبلي والاختبار Sampel T Test) } \\
& \text { البعدي.ونتيجة البحث في هذه الرسالة عن تعليم مهارة القراءة في فصل المراقبة بدون استخدام }
\end{aligned}
$$

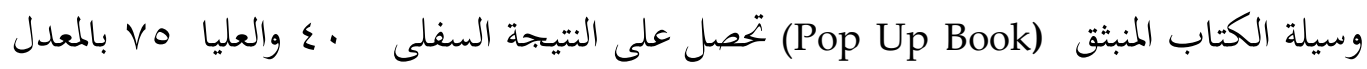
آج، بو و في فصل التجربة بلستخداموسيلة الكتاب المنبثق(Pop Up Book)، يكصل على النتيجة 


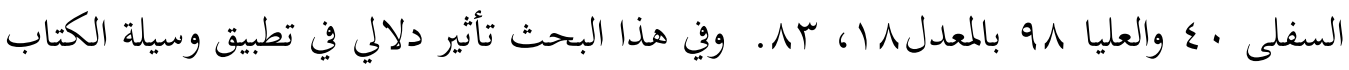

$$
\begin{aligned}
& \text { المنبثق في تعليم اللغة العربية لترقية قدرة التلاميذ على فهم النصوص العربية المقروءة، وهذا بالنظر }
\end{aligned}
$$

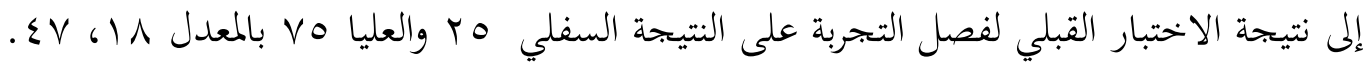

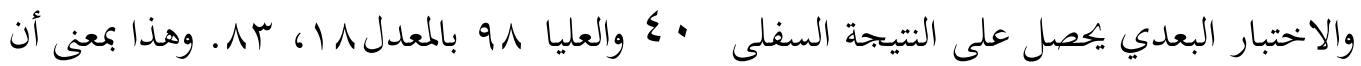

$$
\begin{aligned}
& \text { هناك تأثير استخدام وسيلة الكتاب المنبثق (Pop Up Book) على ترقية فهم التلاميذ على } \\
& \text { النصوص العربية المقروءة. } \\
& \text { الكلمة الرئيسية: الكتاب المنبثق ، فهم التلاميذ، النصوص العربية }
\end{aligned}
$$

\section{Pendahuluan}

Bahasa Arab Merupakan bahasa orang Arab dan orang-orang muslim, akan tetapi yang mempelajarinya tidak hanya bangsa arab dan orang-orang muslim saja, melainkan orang-orang selain bangsa arab dan muslim pun juga turut mempelajarinya. Bahasa Arab merupakan salah satu Bahasa Internasional yang banyak digunakan oleh beberapa negara untuk saling berkomunikasi dan saling memberi pemahaman diantara mereka.Sebagaimana kita ketahui bahwasanya Bahasa Arab memiliki empat keterampilan yaitu keterampilan menyimak, keterampilan berbicara, keterampilan membaca dan keterampilan menulis.

Keterampilan membaca merupakan salah satu keterampilan yang wajib dimiliki oleh setiap pembelajar bahasa apalagi bahasa asing. Membaca merupakan keterampilan yang pokok dalam pembelajaran bahasa disamping keterampilan-keterampilan yang lain yaitu menyimak, berbicara dan menulis. ${ }^{1}$ Disamping itu, bahwasanya salah satu dari tujuan membaca adalah pahamnya siswa terhadap apa yang dibaca dengan pemahaman yang baik, karena paham akan teks-teks yang dibaca merupakan salah satu dari tujun membaca. ${ }^{2}$

Mts An-Nur Kota Cirebon merupakan salah satu sekolah islam yang ada di Kota Cirebon. Di sekolah ini bahasa arab dipelajari dengan segala keterampilannya. Akantetapi, sangat disayangkan para guru diskolah ini tidak menggunakan media pembelajaran yang bermacam-

${ }^{1}$ Muhammad 'Ali al-Khoali, Strategi Pembelajaran Bahasa Arab. (Yogyakarta: Basan Publising, 2010). Hal. 107. 4.

${ }^{2}$ P. Newmark, A Teks Book Of Translation. (Hertfordshire: Prentice Hall, 1988). Hal. 
macam. Para guru hanya menggunakan buku pembelajaran bahasa arab saja. Begitu juga metode yang digunakan membosankan bagi siswa. Hal ini dapat dilihat dari hasil wawancara peneliti dengan salah satu siswa kelas VIII disekolah ini yang bernama Hafiz pada tanggal 22 November 2018. Bahwasanya para guru bahasa arab tidak menggunakan media yang bermacam-macam dalam kegiatan pembelajarannya dan hanya menggunakan metode konvensional saja, hal ini memyebabkan para siswa menjadi bosan, mereka merasa ngantuk dan saling ngobrol ketika kegiatan pembelajaran. Hal tersebut memberikan pengaruh terhadap kurangnya efektifitas dalam pembelajaran mereka dan mempengaruhi juga terhadap lemahnya motivasi mereka serta kemampuan mereka dalam memahami teks-teks bahasa arab yang dibaca.

Setelah dilaksanakannyaobservasi di sekolah ini pada tanggal 22 November 2018, banyak siswa di sekolah ini yang merasa kesulitan dan bosan dalam belajar bahasa arab khususnya dalam memahamai teks-teks bahasa arab. Diantara kesulitan yang dirasakan para siswa adalah mereka merasa sulit dalam memahami teks-teks bahasa arab yang dibaca dan di antara bosan nya mereka dalam belajar bahasa arab adalah mereka tidak memperhatikan penjelasan materi yang disampaikan oleh guru, mengantuk serta saling ngobrol ketika kegiatan pembelajaran berlangsung. Hal tersebut menyebabkan rendahnya minta mereka dalam belajar bahasa arab sehingga banyak ditemui diantara mereka yang tidak mampu memahami teks-teks bahasa arab yang dibaca.

Melihat dari tes yang telah dilakasanakan di sekolah ini pada tanggal 22 November 2018, diketahui bahwa hasil tes Ujian Tengah Semester Ganjil tahun ajaran 2018/2019 di kelas VIII B dari 30 siswa yang mengikuti tes tersebut daloam materi Bahasa Arab adalah sebagai berikut : 


\section{Hasil Tes UTS}

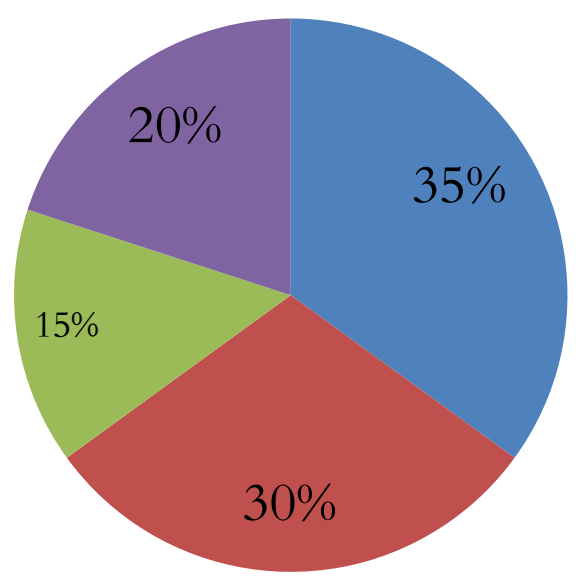

Menyimak

- Berbicara

Membaca

Menulis

Dari diagram diatas dapat di ketahui bahwa Nilai siswa salam pembelajaran bahasa Arab Khususnya dalam keterampilan membaca sangatlah rendah. Dari sini dapat diketahui bahwa para siswa kesulitan dalam memahami teks-teks bahasa Arab yang dibaca.

Karena para siswa merasa kesulitan dan tidak minat terhadap pembelajaran bahasa arab khususnya dalam keterampilan membaca dan daiantara cara untuk meningkatkan kemampuan mereka dalam keterampilan membaca khususnya dalam memahami teks-teks bahasa rab yang dibaca yaitu dengan adanya suatu media pembelajaran, hal tersebut dikarenakan media pembelajaran memiliki makna serta peran yang penting dalam kegiatan belajar mengajar. Materi yang yang dirasakan sulit oleh siswa ketika sedang disampaikan akan menjadi mudah ketika menggunakan medi pembelajran yang sesuai, mereka akan merasa mudah dalam menyerap materi pembelajaran. ${ }^{3}$

Dengan menggunakan media pembelajaran yang bermacammacam merupakan salah satu usaha untuk meningkatkan keberhasilan dalam kegiatan belajar mengajar. Oleh karenanya, dengan menggunakan media pembelajaran yang bermacam-macam dalam kegiatan belajar,

${ }^{3}$ Dzamarah Syaiful Bachri dan Aswan Zain, Strategi Belajar Mengajar. ( Jakarta: PT. Rineka Cipta , 2006). Hal. 136-137. 
murid akan lebih banyak menyerap materi yang disampaikan. ${ }^{4}$ Karena penting nya media pembelajaran dalam pembelajaran bahasa arab kususnya dalam keterampilan membaca untuk memudahkan mereka dalam memahami teks-teks bahasa arab yang dibaca, peneliti tertarik untuk meneliti pengaruh penggunaan media Pop Up Book terhadap peningkatan pemahaman siswa dalam memahami teks-teks bahasa arab yang dibaca.

Pop Up Book merupakan buku yang bisa berpotensi gerak dan interaksi melalui penggunaan mekanisme kertas seperti lipatan, slide, gulungan, dan roda. Menurut Ann Montanaro dalam Dzuanda, buku yang berupa pop up ini merupakan sebuah buku yang mempunyai bagian tertentu yang bisa gerak serta memiliki unsur yang berbentuk 3D, buku pop up sama halnya dengan origami, karena keduanya menggunakan teknik dalam melipat sebuah kertas, buku pop up memiliki jenis yang beragam, dari yang sederhana sampai yang sangat sulit dalam pembuatannya. Ketika buku pop up dibuka akan memberikan suatu kejutan disetiap halaman yang sesuai dengan bentuk yang sudah dilipat sebelumnya. ${ }^{5}$

Dari paparan di atas, peneliti iningi mencoba salah satu media pembelajaran dalam pembelajaran keterampilan membaca yaitu dengan menggunakan media Pop Up Book. Dengan media ini diharapkan dapat membuat para siswa merasa senang dan bersungguh-sungguh serta memudahkan mereka dalam memahami pembelajaran. Oleh karenanya, peneliti melakukan sebuah penelitian tentang penggunaan media Pop Up Book dan pengaruhnya terhadap peningkatan pemahaman siswa dalam memahami teks-teks bhasa arab yang dibaca. ( penelitian eksperimen terhadap murid kelas VIII Mts An-Nur Kota Cirebon).

\section{Metode Penelitian}

Penelitian dengan judul "Penggunaan Media Pop Up Book dan Pengaruhnya Terhadap Peningkatan Pemahaman Siswa dalam Memahami Teks-Teks Bahasa Arab yang Dibaca" merupakan penelitian kuantitatif dan menggunakan jenis penelitian Quasi Exsperimental Design. Desain yang digunakan dalam riset ini adalah Non Equivalent

${ }^{4}$ Abdurrakhman Ginting, Esensi Praktis Belajar Mengajar. ( Bandung: PT. Rineka Cipta, 2010). Hal. 140.

${ }^{5}$ Dzuanda, Perancangan Buku Cerita Anak PopUp Tokoh-Tokoh Wayang Berseri, Seri "Gatotkaca". Jurnal LibraryITS Undergraduate (Online), (http://library.its.undergraduate.ac.id, diakses pada 20November 2018), 2011. Hal. 1. 
Control Group Design. Desain ini sama halnya dengan prerest posttest control group design, meskipun untuk penelitian ini kelompok eksperimen maupun kontrol tidak dipilih secara acak. ${ }^{6}$ Rumus Non equivalent control group design dapat dituliskan sebagai berikut:

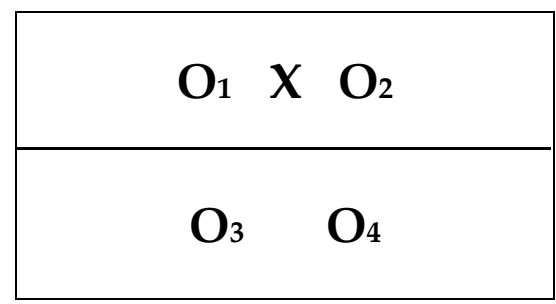

Keterangan : $\mathrm{O} 1=$ Pretest kelas eksperimen

$\mathrm{O} 2=$ Posttest kelas eksperimen

O3 = Pretest kelas kontrol

O4 =Posttest kelas kontrol

$X=$ Perlakuan (Threatment), pembelajaran dengan menggunakan media "pop up book"

Penelitian ini akan dilakukan dalam dua tahapantyaitu pemberian tes awal (pre test) dan pemberian tes akhir (post test). Pemberian tes awal (pre test) dimana pada tahap ini tanpa diberikan perlakuan pada kelas eksperimen da kelas kontrol ditandai dengan $\mathbf{O}_{2}$ dan $\mathrm{O}_{3}$ untuk mengetahui pemahaman siswa akan teks-teks bahasa arab yang dibaca. Pemberian tes akhir (post test) dengan perlakuan (treatment) ditandai dengan $\mathrm{X}$ pada kelas eksperimen yang ditandai dengan $\mathrm{O}_{2}$ dan pada kelas kontrol tanpa diberikan perlakuan ditandai dengan $\mathrm{O}_{4}$ untuk mengetahui pengaruh media pembelajaran pop up book pada peningkatan pemahaman siswa akan teks-teks yang bahasa arab yang dibaca.

Pada kelas eksperimen pembelajaran dilaksanakan dengan menggunakan media "pop up book", sedangkan pada kelas kontrol

${ }^{6}$ Sugiyono, Metode Penelitian Pendidikan Pendekatan Kuantitatif, Kualitatif, dan R\&D. (Bandung: Alfabeta, 2013). Hal. 116. 
pembelajaran dilaksanakan secara konvensional. Penelitian ini dilakukan di MtsAn-Nur Kota Cirebon, sekolah tersebut terletak di Jalan Raya Pangeran Drajat. Kelas yang digunakan untuk melaksanakan penelitian yaitu kelas VIII.

Populasi adalah suatu wilayah generalisasi yang tersusun atas subyek maupun obyek yang mempunyai kualitas dan ciri-ciri tertentu yang dipatenkan peneliti untuk dipahami dan dipelajari serta dibentuk suatu kesimpulan. ${ }^{7}$ Populasi yang dipilih dalam penelitian ini yaitu seluruh siswa kelas VIII Mts An-Nur Kota Cirebon tahun ajaran 2018 / 2019. Jumlah seluruh siswa kelas VIII yaitu 113 Siswa, kelas VIII A terdiri dari 38 siswa, kelas B 39 siswa dan kelas C 36 Siswa. Pada penelitian ini kelas VIIIC sebagai kelas kontrol sedangkan siswa kelas VIII B sebagai kelas eksperimennya.

Sampel adalah wakil ataupun sebagian kecil populasi yang akan diteliti. Pada penelitian yang dilakukan oleh peneliti bahwa teknik untuk mengambil sampel ialah menggunakan sebuah teknik Cluster sampling. Sampel untuk penelitian ini yaitu kelas VIIIC sebagai kelas kontrol sedangkan siswa kelas VIII B sebagai kelas eksperimennya.

Hatch dan Farhady, 1981 dalam Sugiyonomengatakan bahwa variabel merupakan suatu atribut yang dimiliki oleh obyek atau seseorang yang memiliki sebuah "variasi" diantara satu orang dengan orang yang lain dan bisa dikatakan satu obyek dengan obyek yang lain.

Kerlinger 1973 dalam Sugiyonomenjelaskan bahwa variabel merupakan sifat maupun konstrak yang nantinya akan dipelajari. Contoh dari variabel ini misalnya tingkat aspirasi, pendidikan, status sosial, penghasilan, golongan gaji, produktivitas kerja, jenis kelamin dan lain-lain. Karlinger juga menjelaskan bahwa suatu variabel bisa dikatakan sebagai sifat yang akan diambil dari nilai yang berbeda. Maka dengan itu variabel bisa dikatakan sesuatu yang bervariasi. Untuk pendapat selanjutnya yaitu dari Kidder, Kidder mengatakan bahwa suatu variabel adalah sebuah kualitas yang mana peneliti akan mempelajari dan menarik kesimpulan darinya.

Pada penelitian ini teknik pengumpulan data dapat diukur dengan adanya ketercapaian aspek dan penilaian yang digunakan

7 Sugiyono, Metode Penelitian Pendidikan Pendekatan Kuantitatif, Kualitatif, dan R\&D. (Bandung: Alfabeta, 2013). Hal. 117. 
sebagai data hasil dari penelitian dalam bentuk instrument penelitian sebagai berikut :

Lembar tes yang digunakan pada penilitian ini terdapat dua jenis tes yaitu pretest dan posttest untuk mengetahui sejauh mana kemampuan siswa dalam memahami teks-teks bahasa arab yang dibaca. Pada lembar tes terdapat beberapa gambar, langkah-langkah pengerjaan dan kolom yang digunakan siswa untuk menjawab sesuai dengan gambar yang disediakan.

Teknikpengumpulan datayang dilakukan dalam penelitian ini akan diperoleh dari teknik pengumpulan data dengan menggunakan teknik tes, observasi dan Wawancara. Teknik tes bertujuan untuk mengetahui kemampuan siswa dalam memahami teks-teks yang dibaca. Tes dilakukan sebanyak dua kali, yaitu pretest dan posttest. Pretest digunakan untukmengetahui kemampuan awal siswa terhadap pemahaman siswa dalam memahami teks-teks bahasa arab yang dibaca sebelum mendapatkan perlakuan. Sedangkan Posttest digunakan untuk mengatahui pemahaman siswa setelah mendapatkan perlakuan. Teknik observasi dialakukan untuk mengamati pelaksanaan kegiatan pembelajaran keterampilan membaca siswa dengan menggunakan media pembelajaran pop up book pada kelas eksperimen secara langsung. Teknik observasi dilakukan untuk mengamati penelitian sebagai guru pelaksana pembelajaran saat melakukan proses pembelajaran, pengamatan dilakukan oleh guru kelas dan teman sejawat.

Suber data yang diambil dalam penelitian ini adalah kepala sekolah untuk mengetahui tentang sekolah serta perkembangannya, guru untuk menngetahu kegiatan pembelajaran serta media pembelajaran apa yang digunakan, stap TU untuk mengetahui tentang keadaan semua sekolah, siswa untuk mengetahui kemampuan mereka dalam memahami teks-teks bahasa arab yang dibaca serta buku yang pelajaran bahasa arab yang berkaitan dengan penelitian ini.

Teknik analisis data ini diperoleh setelah semua data terkumpul dan akan dianalisis sehingga diperoleh hasil yang diperlukan dalam penelitian ini. Pada penelitian ini analisis data instrument menggunakan uji validitas dan uji reliabilitas.

Uji validitas adalah suatu ukuran yang menunjukkan tingkat kevalidan dan kesahihan suatu instrumen. Suatu instrumen dikatakan valid apabila dapat mengungkap data dari variabel yang diteliti secara 
tepat. Validitas dalam penelitian ini diukur menggunakan program pengolahan data SPSS 21 dengan korelasi Product Moment. Kriteria item yang valid yaitu dengan melihat hasil probabilitas. Jika nilai thitung $>$ ttabel maka item dinyatakan valid. Jika thitung<ttabelmaka item dinyatakan tidak valid.

Uji realibitas menunjuk pada satu pengertian bahwa sesuatu instrument cukup dapat dipercaya untuk digunakan sebagai alat pengumpul data karena instrumen sudah baik. Item yang valid akan dilakukan perhitungan reliabilitas dengan menggunakan rumus Cronbach's Alpha dengan tujuan mencari koefisien relibilitasnya. Reliabilitas dari skala ini diketahui dengan menggunakan program SPSS 21.Uji reliabilitas dengan tenik Cronbach's Alpha yaitu dengan cara menentukan nilai varian tiap butir pertanyaan, menentukan nilai varian total dan menentukan reliabilitas instrumen.

$$
\mathrm{r}_{11}=\left(\frac{\mathrm{k}}{(\mathrm{k}-1)}\right)\left(1-\frac{\sum \sigma_{\mathrm{b}}^{2}}{\sigma_{\mathrm{t}}^{2}}\right)
$$

Kriteria uji reliabilitas dengan rumus Cronbach's Alpha menggunakan batasan 0,6. Jika reliabilitas $<0,6$ maka kurang baik, jika reliabilitas 0,7 dapat diterima, dan jika reliabilitas $>0,8$ adalah baik.

Uji normalitas berguna untuk mengetahui setiap sampel yang akan digunakan berasal dari populasi yang terdistrubusi normal atau tidak. Uji normalitas data pada penelitian ini dilakukan dengan menggunakan program pengolahan data SPSS versi 22 melalui uji normalitas Kolmogorov-Smirnov dengan kriteria jika signifikansi $>0,05$ maka data berdistribusi normal, dan jika signifikansi $<0,05$ maka data tidak berdistribusi normal.

Uji Homogenitas dilakukan pada hasil data pretest dan posttestsiswa. Pada penelitian ini, uji homogenitas dilakukan dengan menggunakan program pengolahan data SPSS 22 melalui uji Levene. Kriteria pengujiannya adalah apabila nilai signifikasi atau nilai probabilitas < 0,05 maka data tidak homogen, sedangkan jika nilai signifikasi atau nilai probabilitas $>0,05$ maka data homogen. ${ }^{8}$

${ }^{8}$ Arikunto Suharsimi, Prosedur Penelitian Suatu Pendidikan Praktik. (Jakarta: PT Rineka Cipta, 2013). Hal. 221. 
Uji Hipotesis pada penelitian ini menggunakan teknik t-test. Teknik ini merupakan teknik statistik yang dipergunakan untuk menguji signifikansi perbedaan dua buah mean yang berasal dari dua buah distribusi (Winarsunu, 2015:75). Data yang diperoleh dalam penelitian ini berjenis rasio dan digunakan untuk mengetahui perbedaan nilai pretest dan posttest perhitungannya menggunakan uji t-test. Uji t-test ini nantinya akan dijadikan pembanding antara kelas kontrol dan kelas eksperimen. Adanya alasan menggunakan uji t-test ini yaitu karena tidak adanya keterkaitan antara dua sampel yang digunakan. Maksudnya yaitu anggota yang terdapat pada kelas kontrol tidak menjadi anggota pada kelas eksperimen, begitu juga sebaliknya. Uji t-testpada penelitian ini dilakukan dengan menggunakan program pengelolahan data SPSS versi 21 dengan rumus Indipendent Samples T Test.

\section{Media Pembelajaran}

Kata media berasal dari bahasa latin mediusyang berarti 'tengah' 'perantara' atau 'pengantar'. Gerlach dan Ely dalam Arsyad mengatakan bahwa media adalah manusia, materi atau kejadian yang membangun kondisi yang membuat peserta didik mampu memperoleh pengetahuan, keterampilan atau sikap. Dalam proses pembelajaran, media sering diartikan sebagai alat-alat grafis, photografis atau elektronis yang mampu menangkap, memproses dan menyusun kembali informasi Visual dan Verbal. Sedangkan Gagne dan Briggs dalam Arsyad mengatakan bahwa media pembelajaran meliputi alat yang secara fisik digunakan untuk menyampaikan isi materi pengajaran. ${ }^{9}$ Dengan kata lain, media merupakan komponen sumber belajar atau wahana fisik yang mengandung materi instruksional di lingkungan siswa yang dapat merangsang siswa untuk belajar. Dari pengertian media di atas dapat disimpulkan bahwa media adalah alat bantu fisik yang digunakan dalam proses pembelajaran untuk memudahkan siswa dalam memproleh pengetahuan, keterampilan maupun sikap.

Menurut Hamalik dalam Arsyad bahwa pemakaian media pembelajaran dalam proses belajar mengajar dapat membangkitkan keinginan dan minat yang baru, membangkitkan motivasi dan rangsangan kegiatan belajar dan membawa pengaruh-pengaruh psikologis terhadap peserta didik. Penggunaan media dapat membantu

${ }^{9}$ Arysad Azhar, Media Pembelajaran. ( Jakarta: Rajawali Press, 2007). Hal. 5-15. 
mengefektifkan proses pembelajaran dan penyampaian materi pembelajaran. Selain itu media juga dapat membantu siswa meningkatkan pemahaman, menyajikan materi pelajaran, dengan menrik serta memudahkan dalam menerima materi pelajaran.

Adapun manfaat media dalam proses pembelajaran adalah sebagai berikut:

a. Memperjelas penyajian pesan agar tidak terlalu bersifat verbalistis (dalam bentuk kata-kata atau lisan belaka)

b. Mengatasi keterbatasan ruang, waktu, dan daya indera seperti misalnya :

a) Objek yang terlalu besar bisa digantikan dengan realita, gambar, Film bingkai, film atau model

b) Objek yang kecil dibantu dengan proyektor mikro, film bingkai, film atau gambar

c) Gerak yang terlalu lambat atau terlalu cepat dapat dibantu dengan timeplase atau high-speed Photography

d) Kejadian atau peristiwa yang terjadi dimasa lampau bisa ditampilkan lagi lewat rekaman film, video, film bingkai, foto maupun secara verbal

e) Objek yang terlalu kompleks ( misalnya mesin-mesin) dapat disajikan melalui model, diagram dan lain-lain

f) Konsep yang terlalu luas ( gunung berapi, gempa bumi, iklim dan lain-lain) dapat divisualkan dalam bentuk film, film bingkai, gambar dan lain-lain.

c. Penggunaan media pendidikan yang tepat dan bervariasi dapat mengatasi sikap pasif anak didik.dalam hal ini media pembelajaran berguna untuk :

a) Menimbulkan kegairahan belajar

b) Memungkinkan interaksi yang lebih langsung antara anak didik dengan lingkungan dan kenyataan

c) Memungkinkan anak didik belajar sendiri-sendiri merut kemampuan dan minatnya. 
d. Dengan sifat yang unik pada setiap siswa ditambah lagi dengan lingkungan dan pengalaman yang berbeda, sedangkan kurikulum dan pendidikan ditentukan sama untuk setiap siswa, maka guru banyak mengalami kesulitan bilamana semuanya itu harus diatasi sendiri. Masalah ini dapat diatasi dengan kemampuannya alam:

a) Memberikan perangsang yang sama

b) Mempersamakan pengalaman

c) Menimbulkan persepsi yang sama.

Manfaat dari penggunaan media yakni membantu guru dalam menyampaikan materi dan membantu siswa dalam memahami materi. Dengan menggunakan media maka maka tujuan belajar akan mudah tercapai. Manfaat dari pengguanaan media akan tercapai secara maksimal jika guru dapat memilih dan menggunakan media secara tepat dan sesuai dengan kebutuhan pembelajaran.

Ada beberapa kriteria media berbasis visual, yakni sebagai berikut:

a. Usahakan visual yang sederhana. Penggunaan gambar realistis haruslah hati-hati agar tidak mengganggu perhatian siswa atau guru.

b. Hindari visual yang tidak berimbang

c. Tkankan kejelasan dan ketepatan dalam semua visual.

d. Visual yang diproyeksikan harus dapat terbaca dengan mudah, dan

e. Gunakan warna yang realistis

Adanya kriteria pemilihan media, dapat memudahkan guru dalam memilih media yang sesuai dengan materi serta memudahkan guru dalam menggunakan media untuk membantu dakam pelaksanaan proses pembelajaran melalui penggunaan media diharapkan dapat meningkatkan kualitas proses pembelajaran yang akan berdampak pada kualitas hasil belajar siswa.

\section{Pop Up Book}

Pop Up Book merupakan buku yang bisa berpotensi gerak dan interaksi melalui penggunaan mekanisme kertas seperti lipatan, slide, 
gulungan, dan roda. Menurut Ann Montanaro dalam Dzuanda, buku yang berupa pop up ini merupakan sebuah buku yang mempunyai bagian tertentu yang bisa gerak serta memiliki unsur yang berbentuk 3D, buku pop up sama halnya dengan origami, karena keduanya menggunakan teknik dalam melipat sebuah kertas, buku pop up memiliki jenis yang beragam, dari yang sederhana sampai yang sangat sulit dalam pembuatannya. Ketika buku pop up dibuka akan memberikan suatu kejutan disetiap halaman yang sesuai dengan bentuk yang sudah dilipat sebelumnya.

Menurut Dzuanda buku pop up memiliki kelebihan antara lain:

a. Memberikan sebuah cerita yang menarik dimulai dari adanya tampilan yang berdimensi yaiyu pada gambar dan ketika halaman buku dibuka bagian tertentu nantinya bias bergeser.

b. Memberikan sebuah kejutan yang dapat mengundang ketakjuban ketika halaman buku pop up dibuka yang nantinya pembaca akan menanti kejutan pada halaman berikutnya.

c. Kesan yang disampaikan dalam sebuah cerita semakin kuat. d) tampilan yang mempunyaidimensi membuat cerita seperti nyata dengan ditambahnya kejutan yang ada pada halaman berikutnya.

Dari suatu pendapat yang sudah dijelaskan bisa disimpulkan bahwa media "pop up book" termasuk jenis media 3D yang mampu memberikan efek menarik, karena setiap halamannya dibuka akan menampakkan sebuah gambar yang timbul dan materi yang terdapat di pop up book bisa disesuaikan dengan materi ajar yang ingin disampaikan. Oleh karena itu peran media tersebut tepat untuk diterapkan pada siswa saat pembelajaran, karena dapat menarik siswa untuk belajar dengan baik.

Dzuanda berpendapat bahwa media "pop up book" mempunyai jenis yang beragam antara lain yaitu:

a. Transformation Pop-Up : Dalam kamus bahasa inggris transformation memiliki arti perubahan atau pergantian bentuk. Hal ini berarti salah satu jenis pop up book yaitu transformations pop-up adalah buku pop-up yang mengutamakan bentuk 
transformasi atau perubahan bentuk 3 dimensi yang begitu nyata ketika halamannya di buka.

b. Tunnel Pop Up Book: Tunnel Pop Up Book yang berarti terowongan. Dalam hal ini Tunnel Pop Up Book memiliki makna buku yang menampilkan gambar 3 dimensi yang mendatar menyerupai panggung kecil. Volvelles Pop-Up: Merupakan salah satu jenis pop up book yang mengutamakanbentuk tri matra (3 dimensi).

c. Movable Pop-Up: Movable berarti perpindahan dalam hal ini movable Pop-Up adalah bentuk pop up-book yang cara penggunaannya hanya dengan menggeser atau memindahkan. Bentuk-bentuk 3 dimensi terdapat dalam setiap sisinya dan untuk menggunakannya hanya dengan cara memindahkan setiap sisinya untuk melihat halamanhalaman berikutnya.

d. Pull-Tabs: Pull-Tabs memiliki pengertian salah satu buku pop up yang cara penggunaannya dengan membuka setiap lembaran halaman, namun masih berada dalam 1 lembar kertas (seperti cara membuka leaflet atau brosur).

e. Pop-Outs: Salah satu jenis pop up book yang menampilakan sebuah gambar yang keluar dari bagian dasar horizontal sebuah buku. Media Pop up book yang akan diujicobakan berbentuk persegi panjang yang memiliki ukuran seperti kertas A3. Apabila media tersebut dibuka $180^{\circ}$, maka akan tampak seperti buku. Media ini berbentuk 3D dan mempunyai daya tarik sendiri bagi anak dengan mengetahui kejutan-kejutan di dalamnya. Ketika media tersebut dibuka siswa akan mengetahui isi dari materi tersebut. Penggunaan media pop up book bisa diujicobakan pada seluruh mata pelajaran, khususnya pada mata pelajaran 
matematika dan materi yang disampaikan yaitu luas dan keliling $\mathrm{b}$ persegi, persegi panjang, dan segitiga. ${ }^{10}$

Aditya Dewa Kusuma menyebutkan bahwa ada beberapa macam Media Pop Up Book diantaranya ${ }^{11}$ :

a. Transformations

Merupakan bentuk tampilan yang terdiri dari potonganpotongan pop up yang disusun secara vertikal

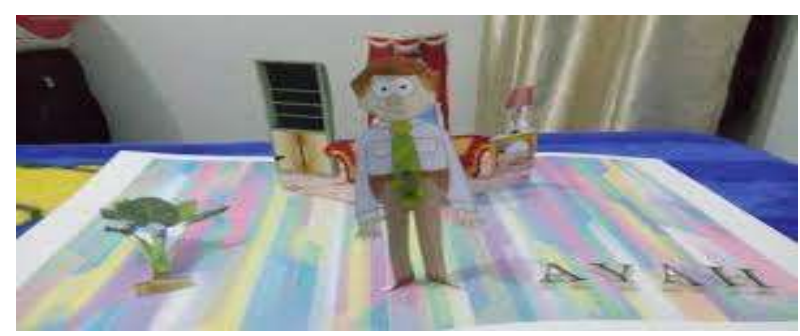

b. Volvelles

Merupakan bentuk tampilan yang menggunakan unsur lingkaran dalam pembuatannya
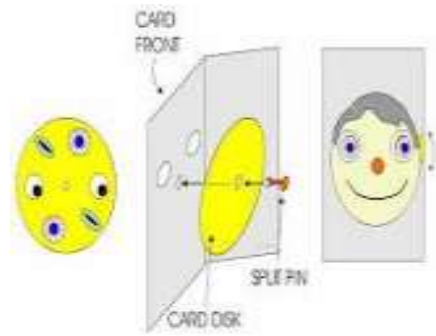

c. Peepshow

Merupakan tampilan yang tersusun dari serangkaian tumpukan kertas yan disusun bertumpuk menjadi satu sehingga menciptakan ilusi kedalam perspektif

10 Dzuanda, Perancangan Buku Cerita Anak PopUp Tokoh-Tokoh Wayang Berseri, Seri "Gatotkaca". Jurnal LibraryITS Undergraduate (Online), (http://library.its.undergraduate.ac.id, diakses pada 20November 2018), 2011. Hal. 1-23.

${ }^{11}$ Aditya Dewa Kusuma, Perancang Buku Pop Up Book, (www.distrodoc.com) diakses pada 7 Juni 2019. 


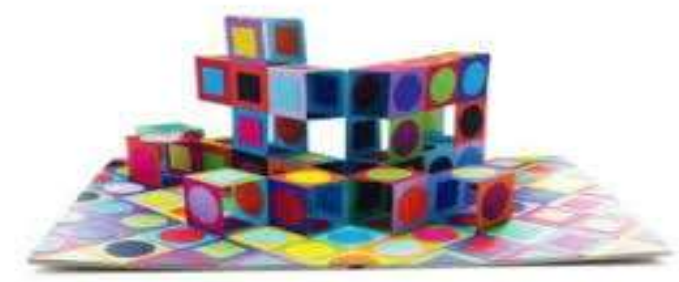

d. Pull-Tabs

yaitu sebuah teb kertas geser atau bentuk yang ditarik dan didorong untuk memerlihatkan gambar baru

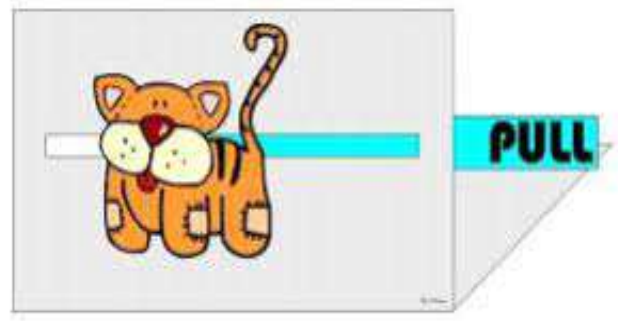

e. Carousel

Adalah jenis yang didukung oleh tali, pita atau kancing yang apabila dibuka atau dilipat kembali berbentuk benda yang komplek.

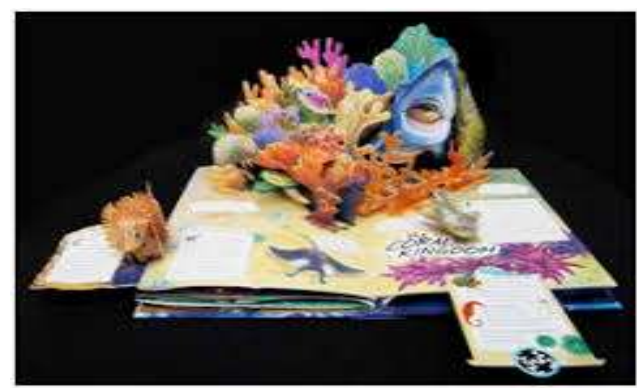

f. Box and Cylinder

Adalah gerakan sebuah kubus atau tabung yang bergerak dari tengah halamam ketika halaman dibuka 


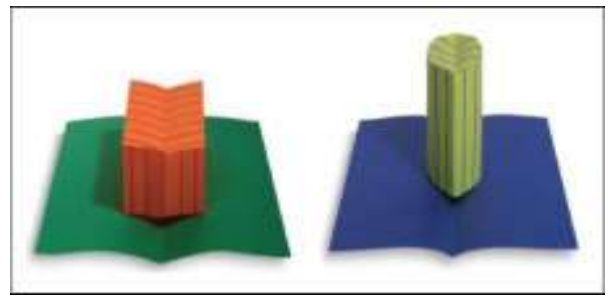

\section{Keterampilan Membaca}

KBBI mendefinsikan membaca adalah melihat serta memahami isi dari apa yang tertulis, dengan melisankan atau hanya dengan hati ${ }^{12}$. Maharaah al-qiraa'ah adalah kemampuan mengenali dan memahami isi sesuatu yang tertulis (lambang-lambang tertulis) dengan melafalkan atau mencernanya di dalam hati. Membaca pada hakekatnya adalah proses komunikasi antara pembaca dengan penulis melalui teks yang ditulisnya. ${ }^{13}$

Menurut Abdul' Alim Ibrahim, ${ }^{14}$ pengertian membaca mengalami perkembangan dari waktu ke waktu. Perkembangan tersebut menurut beliau adalah sebagai berikut:

a. Dulu pengertian qiraa'ah sangat sempit, terfokus pada kemampuan mengungkap dan mengucapkan lambang tulisan. Pembaca yang paling baik dalam pengertian ini adalah yang paling lancar membaca lambang-lambang tulisan tersebut.

b. Pada tahap berikutnya, pengertian di atas, berkembang menjadi aktifitas berfikir disertai pemahaman.

c. Pengertian kedua berkembang lagi dengan ditambah unsur lain yaitu adanya interaksi antara pembaca dengan teks yang bisa membuat pembaca menyetujui, membenci, mengagumi, merasa senang, sedih, dan sebagainya akibat adanya interaksi dengan teks tersebut.

${ }^{12}$ Saefuloh Hasan, Teknik Pembelajaran Keterampilan bahasa Arab (Cirebon: Nurjati Pres, 2012). Hal . 71-72.

${ }^{13}$ Acep Hermawan, Metodologi Pembelajaran Bahasa Arab (Bandung: PT Remaja Rosdakarya, 2011). Hal. 143.

${ }^{14}$ Lihat Abdul 'Alim Ibrahim, Al-Muajjih al-Fanny Li Mudarrisi al-Lughah al-Ababiyyah (Mesir: Dar Al-Ma'arif, 1962). 
d. Akhirnya pengertian di atas berkembang lagi menjadi penggunaan atau pengamalan apa yang dipahami pembaca teks dalam memahami problematika kehidupan. Kalau pembaca tidak mampu mengambil kesimpulan atau pelajaran dari teks yang dibacanya, maka dalam pengertian yang terakhir ini, menurut Abdul'Alim Ibrahim, ia belum dianggap "Membaca".

Senada dengan ibrahim, Ilyan ${ }^{15}$ mengemukakan bahwa membaca dalam arti yang lebih luas adalah "mengucapkan simbol tulisan disertai pemahaman, berinteraksi dengan teks, menganalisis kandungan teks dan mengkritisinya, serta memanfaatkan kandungan bacaan sebagai sarana pemecahanmasalah, dan menghibur".

Ada beberapa jenis dalam membaca yaitu :

a. Membaca Nyaring (qiraa'ah al-jahriyyah) ${ }^{16}$

Membaca nyaring adalah membaca dengan melafalkan atau menyuarakan simbol-simbol tertulis berupa kata-kata atau kalimat yang dibaca. Latihan membaca ini lebih cocok diberikan kepada pelajar tingkat pemula.Sesuai dengan sebutan bacaan ini, maka tujuan utamanya agar para pelajar mampu melaplkan bacaan dengan baik sesuai dengan sistem bunyi baasa arab.

Membaca nyaring merupakan merupakan teknik terbaik untuk melatih kelancaran pengucapan, performance dalam membaca, dan mengekspresikan makna terutama untuk siswa pemula. Membaca nyaring juga mempermudah guru untuk memantau kesalahan-kesalahan pada siswa sehingga sehinga bisa segera membetulkannya. Membaca nyaring juga melatih siswa agar terbiasa untuk mempersiapkan diri pada profesi tertentu seperti membaca berita, penceramah, pembaca puisi, atau penyair radio dan televisi.

b. Membaca Diam/dalam Hati ( al-qiraa'ah al-shamitah $)^{17}$

15 Lihat Ahmad Fuad Mahmud Ilyan, Al-Mharat al-Lughawiyyah : Mahiyatuha Wa Thari'q Tadrisina (Riyadh: Dar al-Muslim Li al-Nasyr wa al-Tauzi, 1992).

${ }^{16}$ Baca Acep Hermawan, Metodologi Pembelajaran Bahasa Arab. (Bandung: PT Remaja Rosdakarya, 2011).

${ }^{17}$ Lihat Hasan Saefuloh, Teknik Pembelajaran Keterampilan bahasa Arab. (Cirebon: Nurjati Press, 2012). 
Membaca dalam hati adalah membaca yang dilakukan hanya dengan menggunakan mata tanpa suara atau bisikan, bahkan tanpa memggerakan bibir. Maksudnya simbol-simbol tulisan berubah menjadi makna dibenak pembaca tanpa melalui fase pengucapan. Sedangkan tujuan utama membaca dalam hati adalah penguasaan dan pemahamaan, baik pemahamaan secara global ataupun rincian-rinciannya.

Unsur pokok dari membaca dalam hati adalah pemahaman dan kecepatan. Oleh karena itu siswa harus dilatih menguasai dan memahami bahan yang dibacanya dengan memperhatikan kecepatan dalam membaca.

Adapun tujuan dari pembelajaran keterampilan membaca adalah

a. Tujuan pengajaran untuk pemula fokus pada pencapaian kompetensi pengucapan atau melek huruf, yaitu mengenali lambang bunyi bahasa dan melafalkan nya dengan baik dan benar sesuai aturan ponetik dan tata bahasa arab

b. Tujuan pembelajaran membaca tingkat lanjut diarahkan pada pencapaian kompetensi pemahaman atau fahm al-maqru', yaitu melatih siswa untuk memahami, dan memetik makna dari lambang-lambang yang tersaji dalam bahasa tulis.

Pengaruh Penggunaan Media Pop Up Book Terhadap Pemahaman Siswa

Pada tes ini dimulai dengan memberikan pretes di kelas kontrol. Waktu yang diberikan sekitar 20 Menit. Setelah dilaksanakan pretes peneliti melaksanakan pembelajaran ketemapilan membaca dengan tanpa menggunakan media pop up book. Setelah pemeblajaran selesai dan untuk mengetahui pemahan siswa peneliti melaksanakan postes untukmengetahui perbedaan antara hasil dari pretes da postes. Adapun hasilnya adalah sebagai berikut:

Statistics

\begin{tabular}{|l|c|c|}
\hline & pre-tes kontrol & pos - tes kontrol \\
\hline Valid & 36 & 36 \\
Missing & 0 & 0
\end{tabular}




\begin{tabular}{|l|c|c|} 
Mean & 61,25 & 80,69 \\
Median & 62,50 & 80,00 \\
Mode & 70 & 80 \\
Maximum & 75 & 95 \\
minimum & 40 & 60 \\
Sum & 2205 & 2905 \\
& & \\
\hline
\end{tabular}

Diketahui hasil penghitungan SPSS dari nilai pretes dikelas kontrol dengan rata-rata sebesar 61,25, median 62,50, maksimum 75 dan minimum 40. Sedangkan hasil postes dikelas kontrol adalah dengan ratarata sebesar 80.69, Median 80.00, maksimum 95 dan minimum 60.

Pada tes ini dimulai dengan memberikan pretes di kelas Eksperimen. Waktu yang diberikan sekitar 20 Menit. Setelah dilaksanakan pretes peneliti melaksanakan pembelajaran ketemapilan membaca dengan menggunakan media pop up book. Setelah pemeblajaran selesai dan untuk mengetahui pemahan siswa peneliti melaksanakan postes untukmengetahui perbedaan antara hasil dari pretes da postes. Adapun hasilnya adalah sebagai berikut:

\section{Statistics}

\begin{tabular}{|c|c|c|c|}
\hline & & pretes eksperimen & postes eksperimen \\
\hline \multirow{2}{*}{$\mathrm{N}$} & Valid & 39 & 39 \\
\hline & Missing & 0 & 0 \\
\hline Mean & & 47,18 & 83,18 \\
\hline Median & & 45,00 & 85,00 \\
\hline Mode & & 60 & 85 \\
\hline Maksimum & & 75 & 98 \\
\hline Minimum & & 25 & 40 \\
\hline Sum & & 1840 & 3244 \\
\hline
\end{tabular}

Diketahui hasil penghitungan SPSS dari nilai pretes dikelas Eksperimen dengan rata-rata sebesar 47,18, median 45,00, maksimum 75 
dan minimum 25. Sedangkan hasil postes dikelas kontrol adalah dengan rata-rata sebesar 83, 18, Median 85.00, maksimum 98 dan minimum 40.

\section{Uji Normalitas}

Uji normalitas berguna untuk mengetahui setiap sampel yang akan digunakan berasal dari populasi yang terdistrubusi normal atau tidak. Uji normalitas data pada penelitian ini dilakukan dengan menggunakan program pengolahan data SPSS versi 22 melalui uji normalitas Kolmogorov-Smirnov dengan kriteria jika signifikansi $>0,05$ maka data berdistribusi normal, dan jika signifikansi $<0,05$ maka data tidak berdistribusi normal. Adapun hasil dari Uji Normalitas pada penelitian ini adalah sebagai berikut:

Tests of Normality

\begin{tabular}{|c|c|c|c|c|c|c|c|}
\hline & \multirow{2}{*}{ Kelas } & \multicolumn{3}{|c|}{ Kolmogorov-Smirnov a } & \multicolumn{3}{|c|}{ Shapiro-Wilk } \\
\hline & & Statistic & $\mathrm{df}$ & Sig. & Statistic & $\mathrm{df}$ & Sig. \\
\hline \multirow{2}{*}{ Group } & Kontrol & ,210 & 36 & ,040 & ,932 & 36 & ,028 \\
\hline & Eksperimen & 169 & 39 & , 007 & ,939 & 39 & ,035 \\
\hline
\end{tabular}

Dari tabel diatas diketahui bahwa uji normalitas KolmogorovSmirnova dikelas kontrol dan kelas eksperimen sebesar 0,007 dan 0,40 > 0,05. Hal ini berarti dapat kita ketahui data berdistribusi normal.

\section{Uji Homogenitas}

Uji Homogenitas dilakukan pada hasil data pretest dan posttestsiswa. Pada penelitian ini, uji homogenitas dilakukan dengan menggunakan program pengolahan data SPSS 22 melalui uji Levene. Kriteria pengujiannya adalah apabila nilai signifikasi atau nilai probabilitas < 0,05 maka data tidak homogen, sedangkan jika nilai signifikasi atau nilai probabilitas $>0,05$ maka data homogen.

Test of Homogeneity of Variance

\begin{tabular}{|l|l|l|l|l|}
\hline & Levene Statistic & df1 & df2 & Sig. \\
\hline
\end{tabular}




\begin{tabular}{|ll|r|r|r|r|}
\hline & Based on Mean & 6,516 & 1 & 146 &, 739 \\
Hasil Belajar & Based on Median & 5,917 & 1 & 146 &, 524 \\
Siswa & Based on Median and & 5,917 & 1 & 125,041 &, 524 \\
& with adjusted df & & & &, 683 \\
& Based on trimmed mean & 6,181 & 1 & 146 & \\
\hline
\end{tabular}

Dari tabel diatas diketahui bahwa uji Homogenitas dikelas kontrol dan kelas eksperimen sebesar 0,739>0,05. Hal ini berarti dapat kita ketahui data berdistribusi Homogen.

\section{Uji Hipotesis}

Uji Hipotesis pada penelitian ini menggunakan teknik t-test. Teknik ini merupakan teknik statistik yang dipergunakan untuk menguji signifikansi perbedaan dua buah mean yang berasal dari dua buah distribusi.

Paired Samples Test

\begin{tabular}{|c|c|c|c|c|c|c|c|c|}
\hline & \multicolumn{5}{|c|}{ Paired Differences } & \multirow[t]{3}{*}{$\mathrm{T}$} & \multirow[t]{3}{*}{$\mathrm{df}$} & \multirow{3}{*}{$\begin{array}{l}\text { Sig. } \\
(2- \\
\text { taile } \\
\text { d) }\end{array}$} \\
\hline & \multirow[t]{2}{*}{ Mean } & \multirow[t]{2}{*}{$\begin{array}{l}\text { Std. } \\
\text { Deviat } \\
\text { ion }\end{array}$} & \multirow[t]{2}{*}{$\begin{array}{l}\text { Std. } \\
\text { Error } \\
\text { Mean }\end{array}$} & \multicolumn{2}{|c|}{$\begin{array}{c}\text { 95\% Confidence } \\
\text { Interval of the } \\
\text { Difference }\end{array}$} & & & \\
\hline & & & & Lower & Upper & & & \\
\hline $\begin{array}{ll} & \text { pretes } \\
\text { Pair } & \text { eksperimen } \\
1 & \text { - postes } \\
& \text { eksperimen }\end{array}$ & $-36,000$ & 13,217 & 2,116 & $-40,284$ & $-31,716$ & $-17,010$ & 38 & ,000 \\
\hline
\end{tabular}

\section{Kesimpulan}

Pemahaman siswa terhadap teks-teks bahasa arab yang dibaca tanpa menggunakan media pop up book di kelas kontrol rendah, hal tersebut dapat dilihat dari hasil pretes dengan rata-rata sebesar 61,25, median 62,50, maksimum 75 dan minimum 40. Sedangkan hasil postes dikelas kontrol adalah dengan rata-rata sebesar 80.69, Median 80.00, maksimum 95 dan minimum 60. Hal ini berarti tidak terdapat peningkatan yang besar pada hasil tes.

Pemahaman siswa terhadap teks-teks bahasa arab yang dibaca dengan menggunakan media pop up book di kelas Eksperimen tinggi, 
hal tersebut dapat dilihat dari hasil pretes dengan rata-rata sebesar 47,18, median 45,00, maksimum 75 dan minimum 25. Sedangkan hasil postes dikelas kontrol adalah dengan rata-rata sebesar 83, 18, Median 85.00, maksimum 98 dan minimum 40. Hal ini berarti terdapat peningkatan yang besar pada hasil tes.

Terdapat pengaruh yang signifikan dari pemberian perlakuan terhadap pemahaman siswa dalam memahami teks-teks bahasa arab yang dibaca dengan menggunakan media pop up book. Hal ini dibuktikan dari perhitungan T-Test dengan menggunakan analisis SPSS 21. Hasil yang diperoleh dari perhitungan tersebut adalah nilai Sig.(2 tailed) sebesar 0,000. Hasil sig. (2 tailed) sebesar 0,000 yang berarti bahwa nilai ini lebih kecil dari 0,05 dimana dapat disimpulkan bahwa $\mathrm{Ha}$ diterima dan Ho ditolak.

\section{Daftar Pustaka}

Al-Khuli, Muhammad Ali.2010. Strategi Pembelajaran Bahasa Arab. Yogyakarta:Basan Publishing.

Arikunto, Suharsimi. 2013. Prosedur Penelitian Suatu Pendekatan Praktik. Jakarta: PT. Rineka Cipta.

Azhar, Arysad. 2007. Media Pembelajaran, Jakarta: Rajawali Press

Djamarah, Syaiful Bahri dan Aswan Zain. 2006 .Strategi Belajar Mengajar. Jakarta: PT. Rineka Cipta.

Dzuanda. 2011. Design/Pop Up Child Book Puppet Figura Series? Gatotkaca?. Jurnal Library ITS Undergraduate (Online), (http:// library.its.undergraduate.ac.id, diakses pada 20 November 2018)

Ginitings, Abdurrakhman. 2010. Esensi Praktis Belajar Mengajar. Bandung: PT. Rineka Cipta.

Hermawan, Acep.2011.Metodologi Pembelajaran Bahasa Arab . Bandung: PT Remaja Rosdakarya

Ibrahim,Abdul 'Alim. 1962. Al-Muajjih al-Fanny Li Mudarrisi al-Lughah alAbabiyyah . Mesir: Dar Al-Ma' arif

Ilyan, Ahamad Fuad Mahmud. 1992. Al-Mharat al-Lughawiyyah: Mahiyatuha Wa Thari'q Tadrisina . Riyadh: Dar al-Muslim Li alNasyr wa al-Tauzi 
Kusuma, Aditya Dewa. Perancang Buku Pop Up Book, (www.distrodoc.com) diakses pada 7 Juni 2019

Newmark, P. 1988. A Textsbook Of Translation. Hertfordshire : Prentice Hall

Saefuloh, Hasan. 2012.Teknik Pembelajaran Keterampilan bahasa Arab Cirebon: Nurjati Pres.

Sugiyono. 2013. Metode Penelitian Kuantitatif Kualitatif dan RED. Bandung: Alfabeta.

Suharsimi, Arikunto.2013. Prosedur Penelitian Suatu Pendidikan Praktik. Jakarta: PT Rineka Cipta 